\title{
SOLEDAD VARELA ORTEGA (2005): MORFOLOGÍA LÉXICA: LA FORMACIÓN DE PALABRAS MADRID, GREDOS, 128 PÁGS.
}

\author{
Azucena Penas Ibáñez \\ Universidad Autónoma de Madrid \\ azucena.penas@uam.es
}

La autora de la obra reseñada es una reconocida especialista en morfología del español. Libros como La formación de palabras (ed.) (Madrid, Taurus, 1993) o Fundamentos de morfología (Madrid, Síntesis, 1996²), además de otros importantes trabajos sobre distintos temas morfológicos -entiéndase capítulos de libros, artículos, conferencias, ponencias... etc.-, acreditan una valiosa investigación, seria y rigurosa, en dicha materia.

El libro se centra en la morfología léxica, más exactamente en la formación de palabras. La obra consta de una introducción y seis capítulos, dedicados respectivamente a: 1. El análisis de la palabra compleja; 2. La derivación; 3. La sufijación; 4. La prefijación; 5. La composición; y 6. Otros procesos de formación de palabras: acortamientos, siglas y acrónimos.

1. La introducción tiene la ventaja de no ser una mera declaración de intenciones sino de constituir todo un corpus doctrinal, que la autora ha sabido muy bien sintetizar a partir de su amplia experiencia en el análisis teórico de todos los temas que trata, como son: el vocabulario, la formación de palabras, los neologismos semánticos, la terminología, las creaciones léxicas del lenguaje literario, los vulgarismos y coloquialismos.

Dicha introducción viene acompañada de unas referencias bibliográficas, seleccionadas y comentadas temáticamente, que sirven también como propuesta de lecturas tanto para alumnos universitarios como para licenciados y/o doctores investigadores, por lo que resultan muy útiles a la hora de orientar, ya que verifican el alto grado de conocimiento y de consulta que han supuesto por parte de la persona que las propone.

También la introducción viene seguida de una nutrida batería de ejercicios que permiten adecuar y contrastar teoría con práctica. Los ejercicios son muy completos; abarcan diferentes enfoques: fundamentalmente el sincrónico, pero sin excluir el diacrónico cuando así lo requiere la explicación del fenómeno tratado; principalmente el paradigmático, pero sin perder de vista el sintagmático por las implicaciones contextuales y pragmáticas que conlleva; igualmente, atiende a los distintos registros, niveles y planos: el real y el *virtual, dado que, muy especialmente estos dos últimos planos, ofrecen la oportunidad de reflexionar sobre lo que es y lo que podría ser, concediendo así un espacio al destinatario del libro para ejercitar su competencia lingüística.

El hecho de ilustrar la introducción con una propuesta de lecturas y con una abundante y representativa serie de ejercicios, no es en absoluto algo esporádico en este libro; antes bien, se erige en un principio metodológico, puesto que de forma sistemática se aplica a los 
seis capítulos siguientes. Hecho que redunda en la aportación de coherencia a una obra bien trabada.

2. En el capítulo primero resulta reseñable la eficaz segmentación de la palabra en morfemas. Se marca de modo muy claro el principio de continuidad $\rightarrow$ sucesividad $\rightarrow$ linealidad, tan necesario para el plano del significante como para el plano del contenido, porque permite, a su vez, esquematizar de forma muy gráfica, la relación jerárquica que establecen los diversos formantes en una representación distribucional de corchetes incrustados y etiquetados categorialmente.

3. En el capítulo segundo, continuando el procedimiento de segmentación anterior, se formalizan muy acertadamente los desajustes entre estructura formal e interpretación semántica en las formaciones con estructuras antitéticas.

4. En el capítulo tercero, se ofrece una amplia gama de criterios para clasificar los sufijos. Se priorizan el principio formal de categoría gramatical y el principio semántico de base léxica.

5. En el capítulo cuarto, concretamente en el apartado 4.2., se establecen las diferencias fundamentales entre prefijos y preposiciones, y se argumenta con razones de peso la tesis que defiende la clasificación del prefijo como un tipo de afijo léxico y la consideración de que el proceso por el cual se une a un lexema es un caso de derivación y no de composición.

Resultan también muy interesantes las relaciones que los prefijos establecen con la sintaxis, demostrándose así que, con la derivación de una palabra mediante la adición de un prefijo, se producen cambios sintácticos y semánticos que afectan a la combinatoria de las nuevas piezas léxicas.

Se ofrecen sutiles observaciones acerca de la coordinación de prefijos. Por ejemplo, se aporta una restricción semántica que me parece importante para su reconsideración, como es el hecho de constatar que se coordinan prefijos del mismo campo léxico, bien antitéticos, bien sinónimos. Circunstancia que permite hacer una llamada de atención al concepto de sinonimia y al de antonimia, en tanto en cuanto que siendo ambos fenómenos semánticamente asimétricos se comportan sintácticamente como si no lo fueran.

Tanto la sufijación como la prefijación presentan tablas con el inventario de los sufijos y prefijos que están activos en la formación de palabras del español actual, eliminando las formas cultas, poco usadas o limitadas a los lenguajes de especialidad.

6. El capítulo quinto se ocupa de la palabra compuesta. En él se dan seis pruebas de orden sintáctico para definir la naturaleza de un componente ortográfico o léxico y se distingue entre este tipo de compuesto y las condensaciones fijas de oraciones que no reflejan un proceso activo de formación de palabras. Además de las pruebas de orden sintáctico también se aportan pruebas de orden fonológico y morfológico.

Por otra parte, se define también el compuesto sintagmático, subclasificado en compuesto preposicional y compuesto yuxtapuesto, con una vasta gama de ejemplos, muchos de ellos contrastados en clase, con el fin de ilustrar una exhaustiva casuística.

7. Por último, el apartado seis trata de otros procesos de formación de palabras como acortamientos, siglas y acrónimos. Se plantean cuestiones de interés actual como casos fronterizos y casos dudosos entre palabras compuestas de dos formas acortadas y acrónimos, ofreciendo una vez más razones lingüísticas basadas en pruebas formales que apoyan la tesis defendida. Con ello se hace un notable esfuerzo por detallar, matizar, especificar, delimitar y definir, de forma exhaustiva, los tipos y subtipos correspondientes a los diferentes procesos 
de formación de palabras a lo largo de todo el libro. Como consecuencia, se logra alcanzar con éxito un doble fin: el pedagógico de claridad y el investigador de precisión y exactitud.

El libro termina con un apartado final dedicado a las respuestas a los ejercicios propuestos, a modo de guía que respeta la libertad de elección por parte del receptor ante la propuesta que la autora realiza, pero que no impone con una única solución cerrada, blindada. Característica que otorga al libro, que con gusto reseño, un valor añadido al que ya tiene de por sí su indudable calidad conceptual.

Resulta, por último reseñable, el hecho de que en los ejemplares ahora a la venta se han incorporado algunas correcciones y algunos añadidos, como los sufijos verbalizadores, que completan aún más si cabe la investigación llevada a cabo. 